\title{
Hepatoprotective effect of Zinc and Magnesium against subchronic Cadmium toxicity on biochemical, histopathological and neurobehavioral parameters in Wistar rats
}

\author{
Mohamed Kouadria - Samir Djemli (iD. Abdelkrim Tahraoui
}

M Kouadria - S Djemli (Corresponding author) - A

email: s_djemli@yahoo.fr

Tahraoui

Applied Neuroendocrinology Laboratory, Department of

Biology, Faculty of Sciences, University Badji Mokhtar, Sidi

Amar, Annaba, Algeria.

Received: October 10, 2019 • Accepted: November 03, 2019 • Published Online: November 18, 2019

\begin{abstract}
The aim of this study was carried out to investigate the possible hepato protective effect of Zinc and Magnesium against subchronic cadmium toxicity on biochemical, histopathological and neurobehavioral parameters in Wistar rats during 90 days. Fourty Wistar rats, were randomly divided in four experimental group: 1, control only water; 2 , water and oral administration $(\mathrm{Cd}) ; 3,(\mathrm{Cd}+\mathrm{Mg})$ in water oral administration; 4, $(\mathrm{Cd}+\mathrm{Zn})$ in water oral administration. Zinc and Magnesium was used to reduce hepatoxicity and

showed also deteriorations of liver structure tissue in comparison with the controls, including extensive degeneration of hepatocytes with necrosis, inflammation, the presence of cellular debris within a central vein and cytological vacuolization. The present investigation indicated that $\mathrm{Cd}$ had toxicity effects on the previous mentioned parameters. However, the supplementation of combined $\mathrm{Zn}$ and $\mathrm{Mg}$ was ameliorated some of these parameters and reduced liver histological alterations caused by $\mathrm{Cd}$ toxicity.
\end{abstract} neurobehavioral disorders induced by Cadmium in Wistar rats. The $\mathrm{Cd}-\mathrm{Zn}$ and $\mathrm{Cd}-\mathrm{Mg}$ groups received $10 \mathrm{mg} / \mathrm{kg}$ of $\mathrm{ZnCl}_{2}, 10 \mathrm{mg} / \mathrm{kg}$ of $\mathrm{MgCl}_{2}$ added to drinking water. The $\mathrm{Cd}$ group received $15 \mathrm{mg} / \mathrm{kg}$ of $\mathrm{CdCl}_{2}$. Blood glucose level and body weight were measured every day. According to the results, which have been obtained. There was a reduction in body weight gain due to $\mathrm{Cd}$ group and an increase liver weight. The results indicated also changes in biochemical parameters, which are characterized by an increase in serum glucose, serum urea, serum creatinine, of animals contaminated with cadmium compared to the control animals. However, the supplementation of $(\mathrm{Zn})$ and $\mathrm{Mg}$ combination improved some but not all the previous parameters. Moreover, the findings showed variation in hematological parameters of $\mathrm{Cd}$ treated animals. In other word, there was a rise in number of white cells, and reduction of red cells counts, hemoglobin concentration and hematocrit percentage, but all these parameters returned approximately to their normal values after combined $\mathrm{Zn}$ and $\mathrm{Mg}$ addition. The neurobehavioral test shows an increase in the number of cells crossed, the number of straightening in the test. Open field in the group exposed to $\mathrm{Cd}$ resulting in locomotors hyperactivity compared to the control and it is minimal in other groups treated with $\mathrm{Zn}$ and $\mathrm{Mg}$. On the other hand, the elevated plus maze (EPM) revealed an increase of the time spent in the closed arms of the cadmium group compared to the control. The results clearly

Keywords: Cadmium, Zinc, Magnesium, subchronic, hepatoprotective, neurobehavioral

\section{Introduction}

Cadmium is a heavy metal, which is widely used in industry, affecting human health through occupational and environmental exposure (Bernard et al 1992; Andersen et al 2004). Studies have shown that exposure to cadmium causes hepatoxicity and neurobehavioral parameters disorders, which is associated with cadmium toxicity in liver and also affects cell proliferation, differentiation, apoptosis and other cellular activities (Brzoska et al 2002).

Zinc is an essential trace element in men, relatively nontoxic (Santon et al 2003), ubiquitous in sub-cellular metabolism and essential component of catalytic sites of enzyme classification (Brzoska and Jakoniuk; Tandon et al 2001). It has been shown in men that zinc has an antioxidant effect and stabilizes cell membranes (Merali and Singhal 1976; Rogalska et al 2009).

Many studies have shown that zinc supplementation can reduce the absorption and accumulation of cadmium at the tissue level, and prevent its harmful actions (Bettger and Dell 1981; Cempel and Janicka 2002).

Studies have indicated that the use of elements such as zinc and magnesium prevents or reduces many toxic effects of 
cadmium on various organs and tissues such as the liver, kidneys, skeleton, and blood (Dhawan and Goel 1996; Nepton et al 2005).

Magnesium, as an essential metal, is a vital cofactor to activate many enzyme systems in humans (Smialowicz et al 1987). Some evidence suggests that $\mathrm{Mg}$ modifies Cadmium absorption in the gastrointestinal system, and it reduces peripheral blood Cadmium (Soldatovic et al 1997; Matovic et al 2011).

It is an essential cofactor for activating many enzyme systems in humans, involved in the metabolism of carbohydrates, lipids, proteins and DNA, interacting directly with the substrate or the enzyme (Dhawan et al 1992; Comhair and Erzurum 2002).

In this study, we investigated the hepatoprotective potential of Zinc Chloride and Magnesium Chloride against subchronic Cadmium chloride oral administration toxicity and neurobehavioral disorders parameters in Wistar rats.

\section{Materials and Methods}

\section{Chemicals}

Cadmium chloride $\left(\mathrm{CdCl}_{2} \cdot 2 \mathrm{H} 2 \mathrm{O}\right)$, zinc chloride $\left(\mathrm{ZnCl}_{2}\right)$, and magnesium chloride $\left(\mathrm{MgCl}_{2} \cdot 2 \mathrm{H} 2 \mathrm{O}\right)$ were obtained from Acros Organics (New Jersey, USA). The kits for urea, glycemia, creatinine, and AST ALT were purchased from the Biopharm Company Algeria. All other reagents and chemicals were of analytical grade quality or higher purity.

Animals

Forty adult (10-week-old) male Wistar rats of initial body weight $200 \pm 50 \mathrm{~g}$ were used in this study. The animals were housed in conventional conditions at a temperature of 25 $\pm 1{ }^{\circ} \mathrm{C}$, with a relative humidity of $50 \pm 10 \%$ and a $12-\mathrm{h} / 12$ $\mathrm{h}$ light/dark cycle. The rats were maintained on ad libitum diet and water throughout the experimental period. All experiments were performed in accordance with the National Institute of Health Guide for the Care and Use of Laboratory Animals (NIH Publications No. 80-23), revised 1996.

\section{Experimental protocol}

The rats were randomly divided into four experimental groups of ten rats each. Control group received only drinking water, $\mathrm{Cd}$ group $\mathrm{Cdcl}_{2}$ was oral administration in drinking water at a dose of $15 \mathrm{mg} / \mathrm{kg}$ for 90 days. $(\mathrm{Cd}+\mathrm{Zn} 15 \mathrm{mg} / \mathrm{kg}+10$ $\mathrm{mg} / \mathrm{kg})$ were oral administration in drinking water, $(\mathrm{Cd}+\mathrm{Mg}$ $15 \mathrm{mg} / \mathrm{kg}+10 \mathrm{mg} / \mathrm{kg}$ ) were oral administration in drinking water respectively. $\mathrm{Cd}, \mathrm{Zn}$, and $\mathrm{Mg}$ doses were chosen based on available literature data (Silvina et al 2004; Nepton et al 2005; Hossam et al 2016).

\section{Anesthesia and tissue sampling}

All animals were anesthetized (ketamine to xylazine, $0.7 \mathrm{mg} / \mathrm{kg}$ ) $24 \mathrm{~h}$ after the administration of the final dose(s). The blood samples were collected from cardiac puncture. Animals were sacrificed by cervical dislocation and the rats' liver was removed. Serum samples were separated by using centrifugation at $2000 \mathrm{rpm}$ for $20 \mathrm{~min}$. Serum samples were used for biochemical analysis. The liver was weighed and was used for histological studies.

\section{Preparation of tissue homogenate}

Frozen tissue samples were quickly weighed and homogenized in phosphate buffer $(100 \mathrm{mM})$ containing EDTA ( $1 \mathrm{mM} ; \mathrm{pH} 7.4 ; 1: 10 \mathrm{w} / \mathrm{v})$ and then centrifuged $\left(12,000 \times \mathrm{g}, 30 \mathrm{~min}, 4{ }^{\circ} \mathrm{C}\right)$. The supernatant was used for biochemical analysis. All procedures were performed at $4{ }^{\circ} \mathrm{C}$.

\section{Biochemical analysis}

Serum chemistry

The sample serums were used in the present study to estimate parameters related to liver function such as urea, creatinine, ALT, AST, glycemia and CBS. Serum levels of urea (ure, urease/glutamate dehydrogenase method), creatinine (cre, kinetic jaffe method), were measured by commercial laboratory kits in a fully automated analyzer, Hitachi 902 (Tokyo, Japan) (Kaplan 1984; Murry 1984).

\section{Neurobehavioral tests}

\section{Open field test}

Hall (1934) proposes the use of a locomotion index as an index of reactivity Emotional seems problematic, especially during the first test session. Indeed, animals can show high locomotion for the purpose of exploring the device, which would show a low emotional reactivity, but also in order to seek an escape from the device, which would indicate a strong reaction emotional (Soubrié 1971).

The device used is a plastic enclosure in the form of a $70 \mathrm{~cm}$ square and $30 \mathrm{~cm}$ high. It is divided into two parts: a peripheral part and a central part (Thèse de Doctorat 2002).

The locomotion in the open field was evaluated by raising the index of locomotion in the peripheral part as well as in the central part as a function of time. These two indices cumulative gives us the total locomotion index in the device (Treit at al 1996; Thèse de Doctorat 2002). This test lasted 5 minutes.

\section{Elevated plus maze test (EPM)}

The second device we chose to use is the plus maze test. In 1955, Montgomery described the rodents' aversion to empty spaces and height during the free exploration session from a familiar environment (Montgomery 1955).

The device is cross-shaped and elevated to a height of $60 \mathrm{~cm}$ on the floor. He is consists of a central part $(10 \times 10$ $\mathrm{cm})$, two open arms $(50 \times 10 \mathrm{~cm})$ without walls, and the other two arms are closed by walls $(50 \times 10 \times 30 \mathrm{~cm})$ that are 
opposed two by two, the whole is made of wood. Opaque plastic edges with a height of $0.5 \mathrm{~cm}$ are attached to the open arms to facilitate entry (Dawson et al 1995) and to allow animals to grip in case of imbalance.

Given the aversion of rodents for empty spaces and height, the open arms of the device are more anxiety provoking than the closed arms. Thus, the principle of the test is based on the conflict of approach / avoidance of the open arms: an animal that explores the open arms will be described as being "not very anxious" and an animal that remains confined in the closed arms of the device will be described as being "Anxious" (Djemli et al 2015).

The test lasts 5 minutes and begins when the rat is placed in the center of the plus maze, facing an open arm to increase the latency of the first entry into an arm, but also the number of entry into the arm thereafter.

\section{Histological studies}

The liver tissues were fixed in $10 \%$ buffered formalin, were embedded in paraffin, and were sectioned at a thickness of $7 \mu \mathrm{m}$. The sections were stained with hematoxylin and eosin stain according to Drury and Wallington (1980).

\section{Statistical analysis}

For statistical analysis, Graph Pad Prism statistics software (version 6) was used. The results of all measurements are presented as mean $\pm \mathrm{SD}$ for ten results. Statistical evaluation of the data was performed using a one-way analysis of variance (ANOVA), when the analysis indicated that a significant difference occurred, the experimental groups were compared by post hoc Fisher's least significant difference (LSD) test. $P$ values less than 0.05 were considered to indicate significant differences between the groups.

\section{Results}

\section{Body and liver Weight}

Body weight was significantly reduced $218 \mathrm{~g}$ and liver weight was markedly increasing 12.1 in the $\mathrm{Cd}$ group when compared with the control group. Body weight was slightly improved after coadministration of $10 \mathrm{mg} / \mathrm{kg} \mathrm{Zn}$ or $\mathrm{Mg} \mathrm{mg} / \mathrm{kg}$ for 90 days as compared to $\mathrm{Cd}$ group. Moreover, administration of $\mathrm{Zn}$ or $\mathrm{Mg}$ during subchronic $\mathrm{Cd}$ intoxication caused a significant decrease in liver damage in comparison with the $\mathrm{Cd}$ group. However, a statistically significant reduction in body weight gain was observed in $10 \mathrm{mg} / \mathrm{kg}$ and10 $\mathrm{mg} / \mathrm{kg} \mathrm{Mg}$ treated group in comparison to $\mathrm{Cd}$ and control groups. (Table1).

\section{Effects on biochemical parameters}

\section{Creatinine}

Our results show a very highly significant $(P<0.001)$ increase in serum creatinine concentration in the $\mathrm{Cd}$ contaminated lot compared with controls. While in $\mathrm{Cd}$ contaminated rats treated with $\mathrm{Zn}$ and $\mathrm{Cd}$-infected and $\mathrm{Mg}$ treated rats, we notice a decrease in serum creatinine compared with $\mathrm{Cd}$. (Figure 1).

Urea

Our results show a highly significant $(P<0.01)$ increase in serum urea concentration in the Cd-contaminated lot compared with controls. While in Cd-contaminated rats treated with $\mathrm{Zn}$ and $\mathrm{Cd}$-infected and $\mathrm{Mg}$-treated rats we notice a decrease in serum urea concentration compared with $\mathrm{Cd}$. (Figure 2).

Table 1 The body and liver weight of rats exposed for 90 days to $\mathrm{Cd}, \mathrm{Cd}+\mathrm{Zn}, \mathrm{Cd}+\mathrm{Mg}$.

\begin{tabular}{lccc}
\hline Groups & Initial Body weight & Final body weight & Liver weight \\
\hline Control & $245.00 \pm 14.35$ & $280.00 \pm 13.44$ & $9.10 \pm 0.36$ \\
$(\mathrm{Cd}) 15 \mathrm{mg} / \mathrm{kg}$ & $240.00 \pm 34.12$ & $218.00 \pm 34.31^{\mathrm{a}^{* *}}$ & $12.1 \pm 0.08^{\mathrm{a}^{* *}}$ \\
$(\mathrm{Cd}+\mathrm{Zn}) 10 \mathrm{mg} / \mathrm{kg}$ & $236.00 \pm 40.65$ & $260.30 \pm 41.29^{\mathrm{b}^{* *}}$ & $8.90 \pm 0.24^{\mathrm{b}^{* *}}$ \\
$(\mathrm{Cd}+\mathrm{Mg}) 10 \mathrm{mg} / \mathrm{kg}$ & $234.00 \pm 16.42$ & $252.00 \pm 15.39^{\mathrm{a}^{* \mathrm{~b}^{*}}}$ & $8.87 \pm 0.29^{\mathrm{b}^{* *}}$
\end{tabular}

Variation in body and liver weight gain in control, Cd-contaminated, Zn-treated, Cd-contaminated and Mg-treated and Cd-contaminated rats ( $\mathrm{n}=5)$. Values are expressed as mean $\pm \operatorname{SEM}(* P<0.05 ; * * P<0.01 ; * * * P<0.001)$.

Blood glucose level

Our results show a very highly significant $(P<0.001)$ increase in serum glucose concentration in the $\mathrm{Cd}$ contaminated lot compared with controls. While in $\mathrm{Cd}$ contaminated rats treated with $\mathrm{Zn}$ and Cd-contaminated and
Mg-treated rats we do not notice a significant change in serum glucose concentration compared to controls. (Figure 3).

\section{ALT and AST}

The enzymatic activity of alanine aminotransferase (GOT), the results reveal a very highly significant increase $(P$ 
$<0.001)$ in the Cd-contaminated lot compared with controls. On the other hand, in Cd-contaminated rats treated with $\mathrm{Zn}$ and Cd-contaminated and Mg-treated rats, we observe a decrease in the enzymatic activity of alanine aminotransferase (GOT) compared with Cd (Figure 4).

The enzymatic activity of aspartate aminotransferase (GPT), the results obtained reveal a very highly significant

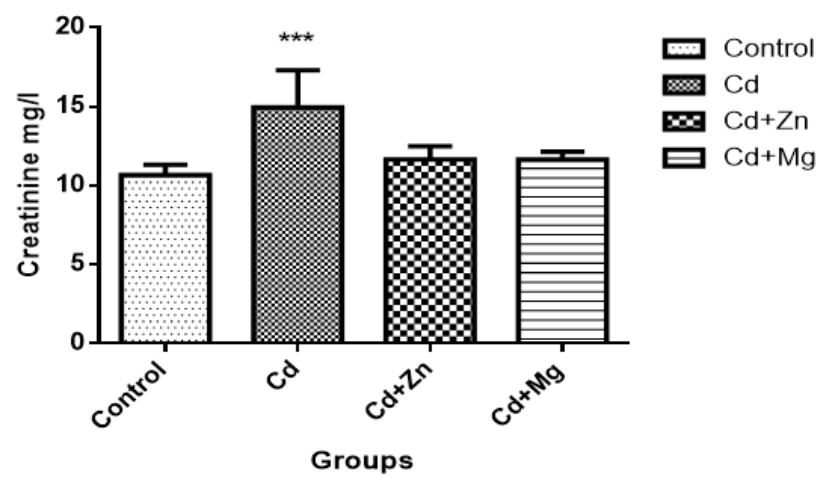

Figure 1 Serum creatinine concentration in control, Cdcontaminated, $\mathrm{Zn}$-treated, Md-contaminated and Cd-contaminated rats $(\mathrm{n}=10)$. Values are expressed as mean $\pm \operatorname{SEM}(* P<0.05 ; * * P$ $<0.01 ; * * * P<0.001)$.

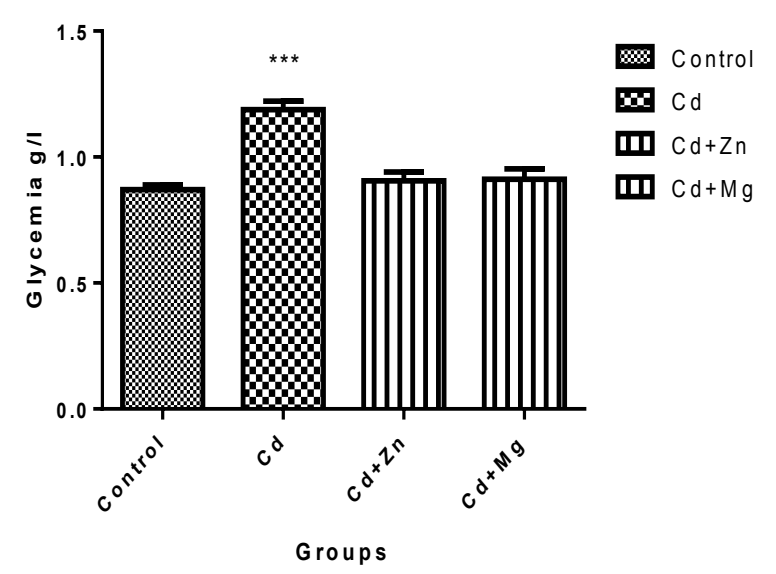

Figure 3 Serum glucose concentration in control, Cd-contaminated, Zn-treated, Cd-contaminated and Cd-contaminated rats $(\mathrm{n}=10)$. Values are expressed as mean $\pm \operatorname{SEM}\left({ }^{*} P<0.05 ; * * P<0.01 ;{ }^{* * *} P\right.$ $<0.001)$.

\section{Effects on hematological parameters}

The results show a very highly significant increase $(P$ $<0.001$ ) of white blood cells in a Cd-contaminated batch compared to the control group, whereas in Cd-contaminated rats treated with $\mathrm{Zn}$ and $\mathrm{Cd}$-infected rats and treated in $\mathrm{Mg}$ we notice a decrease in white blood cell levels compared to $\mathrm{Cd}$ increase $(P<0.001)$ in the batch contaminated with $\mathrm{Cd}$ compared to controls. On the other hand, in Cd-contaminated rats treated with $\mathrm{Zn}$ and $\mathrm{Cd}$-contaminated and $\mathrm{Mg}$-treated rats, we notice a decrease in enzymatic activity of aspartate aminotransferase (GPT) compared with Cd (Figure 5).

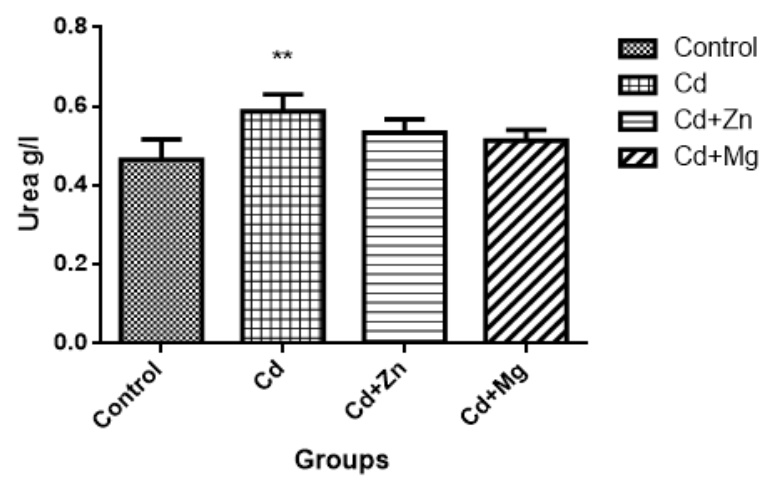

Figure 2 Serum urea concentration in control, Cd-contaminated, $\mathrm{Zn}$-treated, Md-contaminated and Cd-contaminated rats $(\mathrm{n}=10)$. Values are expressed as mean $\pm \operatorname{SEM}(* P<0.05 ; * * P<0.01 ; * * * P$ $<0.001)$.

which confirms the beneficial effect of these two antioxidants ( $\mathrm{Zn}$ and $\mathrm{Mg}$ ) against the toxicity of $\mathrm{Cd}$.

Regarding the rate of red blood cells we noticed a very highly significant decrease $(P<0.001)$ in Cd-contaminated batch compared to the control group, while in the $\mathrm{Cd}$ contaminated rats treated with $\mathrm{Zn}$ and Cd-contaminated rats and treated with $\mathrm{Mg}$ we notice an increase in the rate of red blood cells compared to $\mathrm{Cd}$ which confirms the beneficial effect of these two antioxidants ( $\mathrm{Zn}$ and $\mathrm{Mg}$ ) against the toxicity of $\mathrm{Cd}$.

A very highly significant $(\mathrm{P}<0.001)$ decrease in hematocrit $(\mathrm{HCT})$ in the Cd-contaminated lot compared to the control group, whereas in $\mathrm{Cd}$-contaminated rats treated with $\mathrm{Zn}$ and $\mathrm{Cd}$-contaminated rats and treated with $\mathrm{Mg}$ we notice an increase in hematocrit (HCT) relative to $\mathrm{Cd}$ which confirms the beneficial effect of these two antioxidants ( $\mathrm{Zn}$ and $\mathrm{Mg}$ ) against the toxicity of $\mathrm{Cd}$.

A very highly significant $(P<0.001)$ decrease in hemoglobin $(\mathrm{Hb})$ in the Cd-contaminated lot compared to the control group, whereas in Cd-contaminated rats treated with $\mathrm{Zn}$ and $\mathrm{Cd}$-contaminated rats and treated with $\mathrm{Mg}$ we notice an increase in hematocrit (HCT) relative to $\mathrm{Cd}$ which confirms the beneficial effect of these two antioxidants ( $\mathrm{Zn}$ and $\mathrm{Mg}$ ) against the toxicity of $\mathrm{Cd}$. (Figure 6). 


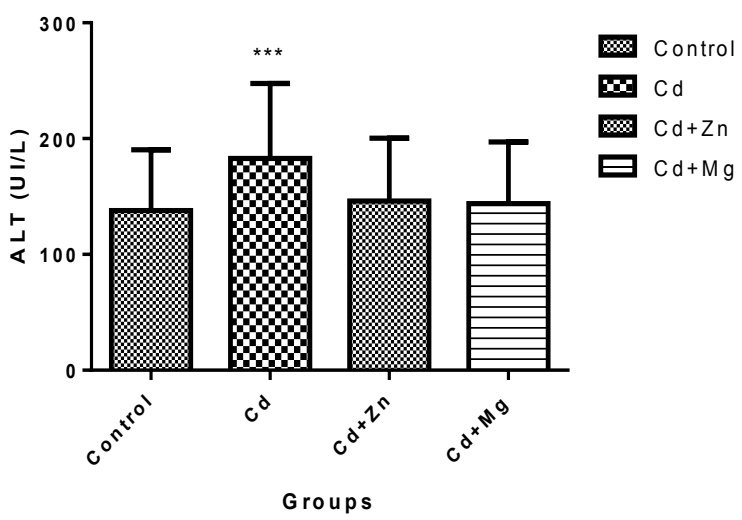

Figure 4 The enzymatic activity of alanine aminotransferase (ALT) in control, Cd-contaminated, $\mathrm{Zn}$-treated, Cd-contaminated and $\mathrm{Mg}$ treated and Cd-contaminated rats $(\mathrm{n}=10)$. Values are expressed as mean $\pm \operatorname{SEM}(* P<0.05 ; * * P<0.01 ; * * * P<0.001)$.

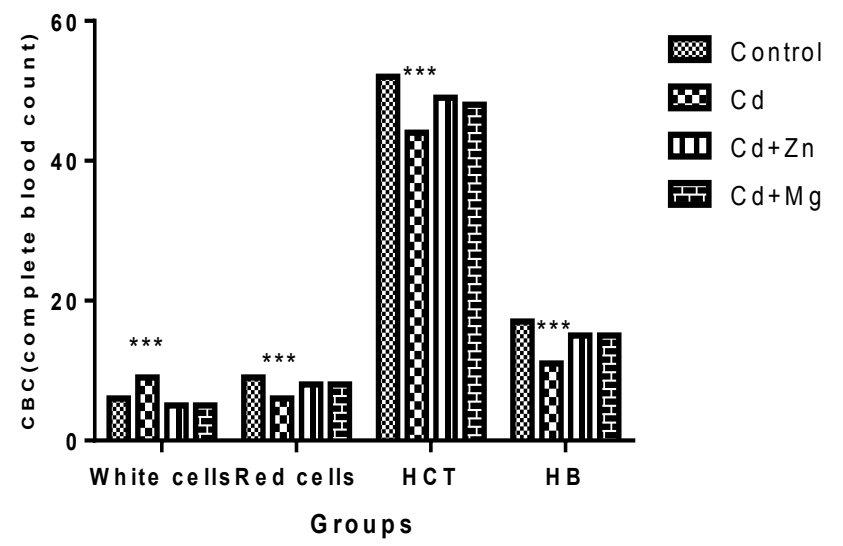

Figure 6 Number of white blood cells, red blood cells, hematocrit and hemoglobin levels in control, Cd-contaminated, Zn-treated, Cdcontaminated, $\mathrm{Mg}$-treated and Cd-contaminated rats $(\mathrm{n}=5)$. Values are expressed as mean $\pm \operatorname{SEM}\left({ }^{*} P<0.05 ; * * P<0.01 ;{ }^{* * *} P<0.001\right)$.

\section{Effects on neurobehavioral parameters}

Open field test

The results of the open field test show a very highly significant increase $(P<0.001)$ in the number of cells crossed in the Cd-contaminated lot compared to the control group, whereas there is no significant change in the number of cells crossed. In Cd-contaminated rats treated with $\mathrm{Zn}$ and $\mathrm{Md}$ treated and $\mathrm{Mg}$-treated rats compared to controls.

A very highly significant increase $(P<0.001)$ in the number of remedies in the Cd-contaminated lot compared with the control group, whereas there was no significant change in the number of cells crossed than in the Cd-contaminated rats treated with $\mathrm{Zn}$ and $\mathrm{Cd}$-contaminated and $\mathrm{Mg}$-treated rats compared to controls.

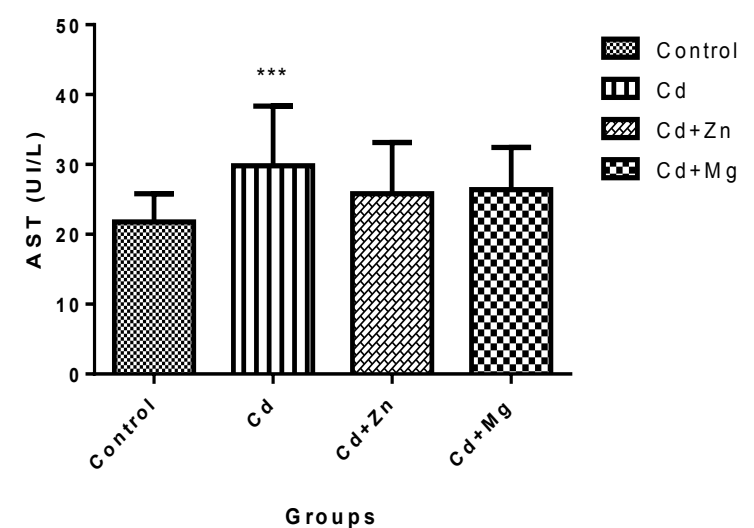

Figure 5 The enzymatic activity of aspartate aminotransferase (TGP) in control, Cd-contaminated, Zn-treated, Cd-contaminated and $\mathrm{Mg}$-treated and Cd-contaminated rats $(\mathrm{n}=10)$. Values are expressed as mean $\pm \operatorname{SEM}(* P<0.05 ; * * P<0.01 ; * * * P<0.001)$.

There was no significant change in the number of visits to the center in the Cd-contaminated lot compared to the control group, the same for the Cd-contaminated rats treated with $\mathrm{Zn}$ and the $\mathrm{Cd}$-contaminated and $\mathrm{Mg}$-treated rats compared to the controls.

Finally, there is a highly significant $(P<0.01)$ increase in the latency time in the $\mathrm{Cd}$-contaminated batch compared to the control group, whereas there is no significant change in the number of cells crossed than in the Cd-contaminated rats treated. $\mathrm{Zn}$ and $\mathrm{Cd}$-infected and $\mathrm{Mg}$-treated rats compared to controls. (Figure 7).

Elevated Plus maze test (EPM)

Based on our results, there was a very highly significant $(P<0.001)$ increase in the number of closed arms entering the Cd-contaminated group compared with the control group. On the other hand, there was no significant change in the number of cells crossed than in the $\mathrm{Cd}$ contaminated rats treated with $\mathrm{Zn}$ and the Cd-contaminated and $\mathrm{Mg}$-treated rats compared to the controls.

No significant change in the number of open arms entered in the Cd-contaminated lot compared to the control group. While there was no significant change in the number of open arms in Cd-treated and $\mathrm{Zn}$-treated rats and Md-treated and $\mathrm{Mg}$-treated rats compared to controls.

There was also a very highly significant $(P<0.001)$ increase in closed-arm time in the Cd-contaminated lot compared with the control group, but no significant change in closed-arm time in contaminated rats. $\mathrm{Cd}$ and treated with $\mathrm{Zn}$ and $\mathrm{Cd}$-infected and $\mathrm{Mg}$-treated rats compared to controls. (Figure 8).

\section{Histological Study}

The normal microscopic architecture of the liver control is composed of hexagonal lobules and acini. 
Hexagonal lobules are centered on the central vein (CV) and have a portal triad containing branches of the portal vein, hepatic artery and bile duct. (Figure 9 A) After administration of $\mathrm{Cd}$ at $15 \mathrm{mg} / \mathrm{kg}$, liver sections revealed mild congestion of the CV and mild disorganization of hepatic cords, additionally, fusions of the portal triad were observed, indicating severe destruction of nearby hepatic lobules and necrosis (Figure $9 \mathrm{~B}$ ). Liver sections from treatment with $\mathrm{Zn}$ and $\mathrm{MG}$ at dose of $10 \mathrm{mg} / \mathrm{kg}$ exhibited mild to moderate congestion of the hepatic artery, sinusoids and portal vein, with dilatation of the PV and moderate disorganization of hepatic cords (Figure $9 \mathrm{C}$ ).

\section{Discussion}

Many studies have shown that most heavy metals such as cadmium, vanadium, lead, nickel, arsenic, cobalt and others are considered toxic agents, disrupting certain enzymatic systems and also the metabolic activities in humans and animals (Who 1992). Moreover, the toxicity of a metal for an organism can be modified by prior, simultaneous, or consecutive exposure to trace elements (zinc, magnesium, selenium, etc.) or vitamins (vitamin $\mathrm{C}$, vitamin $\mathrm{E}$, etc.).

We have attempted in this study to evaluate the impact of a toxic pollutant (cadmium) on Wistar rats. But our

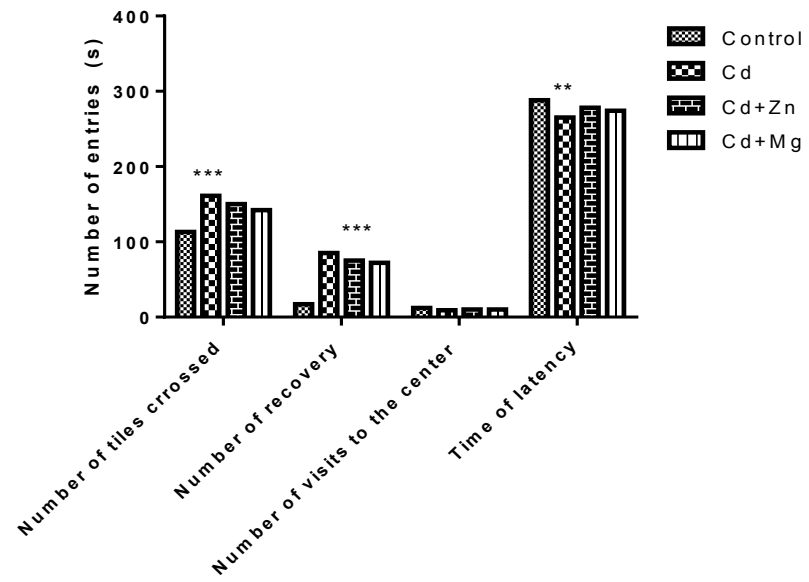

Figure 7 Open field test in control, Cd-contaminated, Zn-treated, $\mathrm{Cd}$-contaminated and Cd-contaminated rats $(\mathrm{n}=5)$. Values are expressed as mean $\pm \operatorname{SEM}(* P<0.05 ; * * P<0.01 ; * * * P<0.001)$.

Simons et al (1995) reported that the increase in liver weights of animals is indicative of the toxicity of the substances used. Our results are consistent with the bibliographic data (Simons et al 1995; Rana et al 1996).

In contrast, the treatment of cadmium-contaminated rats treated with zinc and magnesium resulted in an improvement in body weight and liver weight due to the protective effect of zinc and magnesium against the toxicity of cadmium. attention will be focused on the possible protective action of the combination of zinc and magnesium against the toxic effects of cadmium. For a better understanding of the biochemical, hematological, neurobehavioral and histological mechanisms involved. The results obtained are analyzed and discussed according to works reported in several bibliographies.

Our study shows that exposure to cadmium chloride (15 $\mathrm{mg} / \mathrm{kg}$ for 90 days) affected the body weight of rats; indeed, we noticed a decrease in the growth of cadmiumcontaminated rats compared to controls. (Solomons et al 1982; Erdogan et al 2005). This may be the result of elevated lipid and protein degeneration caused by cadmium (Sugiwara 1977). On the other hand, cadmium reacts with several nutrients. Cadmium affects the metabolism or tissue concentrations of several important elements in bone metabolism in mammals: copper, manganese, magnesium, calcium and zinc. (Washko and Cousins 1977).

Concerning the weight of the organs we notice an increase in weight of the liver in the rats contaminated with nickel. This is explained, on the one hand, by the tissue hypertrophy of the liver caused by this metal and on the other hand, by the intense accumulation of this metal in this target organ to heavy metals.

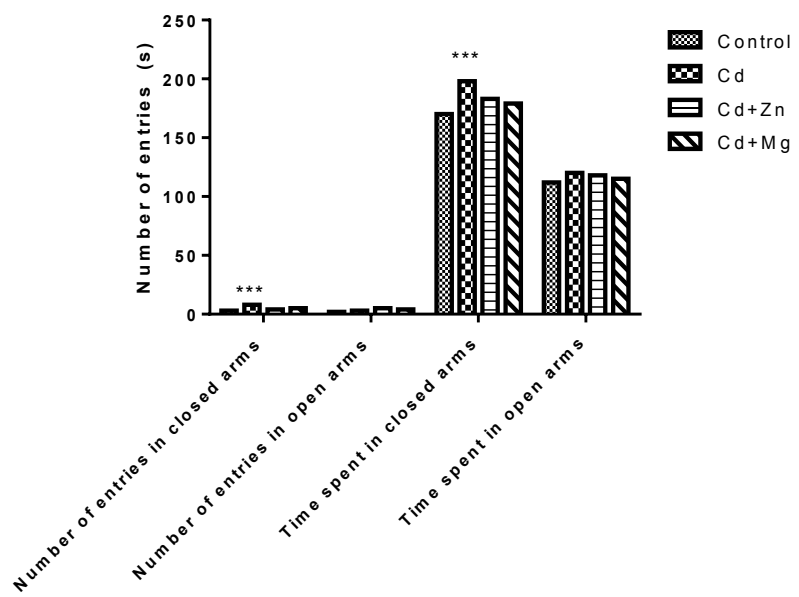

Figure 8 The elevated plus maze test in control, Cd-contaminated, Zn-treated, Md-contaminated and Cd-contaminated rats $(\mathrm{n}=5)$. Values are expressed as mean $\pm \operatorname{SEM}(* P<0.05 ; * * P<0.01 ; * * * P$ $<0.001)$.

The analysis of the results also showed a higher increase in serum glucose concentration in the cadmiumtreated rats. This hyperglycemia is caused by the toxicity of cadmium and is probably due to the toxic action of this metal on the secretory activity of the pituitary gland. It acts by direct inhibition of insulin production by islets of Langerhans (Massanyi et al 1995; Ambali et al 2011) or it blocks the use of glucose by cells and leads to the presence of a high concentration of insulin (Dormer et al 1976) or due to 
disruption in glucagon secretion and leads to high glycogen breakdown, offers new glucose production from other noncarbohydrate sources such as proteins (Sunderman et al 1996).

Treatment with zinc and magnesium will improve glucose concentration in nickel-contaminated rats and this suggests that zinc supplementation will cause a decrease in cadmium effect in salt binding to biomolecules as well as improved insulin secretion by reducing glucose accumulation. Zinc protects enzymes and ATP involved in glucose metabolism. While magnesium could alter insulin receptors in muscle and adipose tissue by increasing the permeability of the membrane to improve glucose uptake (Rana et al 1996).

The increase in serum urea and creatinine levels in cadmium-contaminated rats is considered a biomarker of hepatic and renal dysfunction and hepatic damage caused by this metal. Urea and creatinine are essential parameters for assessing hepatic and $\mathrm{d}$ renal function and glomerular filtration (Finco et al 1997).

Our results show an increase in the enzymatic activity of transaminases (AST, ALT), in the serum of cadmiumcontaminated rats. The increase in these enzymes indicates hepatic injury and is explained by the leakage of enzymes from the tissue to the plasma due to the alteration of the membrane permeability (Noel et al 2006; Matovic et al 2011).

Treatment with zinc and magnesium enhanced the activity of transaminase enzymes AST, ALT in cadmiumcontaminated rats. These antioxidants can stabilize the hepatic cell membrane and protect hepatocytes from the toxic effects of cadmium that can decrease enzyme leakage to plasma. (Uyanik et al 2001; Pari and Murugavel 2005; Djemli et al 2012).

Cadmium can also cause situations of anemias that are more or less important. Thus, it appears that the presence of cadmium in cells causes an overall imbalance in essential metals such as iron (Kostic et al 1993).

The analysis of our results showed that cadmium contamination of the rats caused a significant decrease in red blood cells, hemoglobin and hematocrit. From these results it can be said that cadmium has caused anemia (Matovic et al 2004).

This anemia is due on the one hand; to the effects of free radicals generated by cadmium on red blood cells, or certain free radicals such as: $\mathrm{O}_{2-}$ and $\mathrm{OH}^{-}$are highly reactive species capable of causing cellular damage through the peroxidation of membrane lipids, moreover in the presence high concentrations of these radicals; hemoglobin can readily oxidize (Gurer et al 1998). These results are consistent with the studies (Santon et al 2003; Sameeh et al 2009).

In contrast, there was a clear increase in white blood cells in cadmium-contaminated rats compared with controls. This increase explains that the animal mobilizes all these defense capacities (in particular leucocytes) to fight against the infectious diseases caused by the presence of xenobiotics in its organism (Sidhu et al 2003). This confirms the importance of white blood cells in the immune defense against toxins.

However, this anemia is corrected in grpoups treated with Zinc and magnesium after 90 days of treatment; which further demonstrates the cytotoxic effect of cadmium (Brzoska and Jakoniuk 2000).

We have chosen a battery of neurobehavioral tests to assess the state of depression, anxiety, locomotor activity and a blood glucose test since it is a good indicator stress. These tests were performed to estimate the state of stress in Wistar rats exposed to cadmium compared to controls.

Regarding the open field test the results noted clearly show that oral administration of cadmium showed a very high increase significantly in the number of cells crossed and the number of recovery, which reveals a locomotor hyperactivity in poisoned rats compared to non-intoxicated rats.

This increase in exploration is explained by the action of heavy metals (cadmium) on the dopaminergic system which results in an increase in synthesis, release of the neurotransmitter and hyperfunctioning postsynaptic receivers (Nic et al 2003).

On the other hand, in groups treated with zinc and magnesium we noticed a decrease in the number of cells crossed and the number of recovery this is due to the beneficial and antioxidant power of zinc and magnesium which are trace elements that enter the development of the nervous system and transmission of synaptic signals (Golf et al 1998; Cernaki et al 2000).

Furthermore, we examined the action of cadmium orally on Wistar rats during the most maze test, we noticed a very highly significant increase in the number of entries in the closed arms and the time spent in the closed arms. This is explained by the anxious and depressive state caused by cadmium in Wistar rats.

The plus maze test is one of the most popular behavior patterns for anxiety, the increase in the number of entries and the time spent in the open arms are considered to be the most representative indices of anxiolytic activity.

In this device, the rats prefer to spend much of their time in the closed arms; this behavior seems to reflect an aversion to open arms that is generated by the fear of open spaces. Drugs that increase open-arm exploration are considered anxiolytics and the opposite is true for anxiogens (Slotkin et al 2007; Kouadria et al 2019).

Unlike the cadmium group, lots $\mathrm{Cd}+\mathrm{Zn}$ and $\mathrm{Cd}+\mathrm{Mg}$, show some improvement and decrease in the number of entries in the closed arms, the time spent in closed arms this is explained by the antioxidant capacities of zinc and magnesium to reduce the effect of cadmium on the nervous system by reinforcing dopaminergic and serotonergic transmission in Wistar rats (Dawson et al 1995; Fraia et al 2015). 
The observation of the histological sections that we have carried out reveals that the toxicity of cadmium was manifested by tissue damage to the liver. These alterations are induced, during an oxidative stress, by the increase of the lipid peroxidation. This results in the activation of cellular inflammations and degradation of lipid products. (Rana et al 1996; Kusal et al 2001; Nemmiche et al 2007).

The administration of zinc and magnesium to cadmium resulted in the normalization of liver histology quite substantially. Such beneficial effects of zinc and magnesium in the liver by regulating the levels of different enzymes also have been observed by us earlier while evaluating its potential in nickel toxicity (Tandon et al 1999; Sidhu et al 2006).

Many studies have shown that free oxygen radicals are at the origin of these alterations (Obaiah and Rani 2014). Indeed, these radicals can diffuse into the cytoplasm and across the membranes, to attack cellular components far from their production site or to reach other cells (Waalkes et al 1985).
The attack of the organic components of the cells (lipids, proteins or carbohydrates) allows the transmission of the radical character and thus triggers severe pathologies up to the death of the animals (Mahran et al 2011). It has been reported that subchronic oral exposure of nickel leads to multiple liver necrosis associated with changes in ultrastructure and hepatic changes (Bulat et al 2008; El Refaiy and Eissa 2012).

Although the lamellar model of hepatocytes has been restored to almost normal in zinc treated and magnesium groups, it can be attributed to the ability of zinc and magnesium to reduce the threat of oxygen radicals wich leads to the reduction of pathological change (Djukic et al 2007). The zinc and magnesium provides protection against cadmium induced oxidative stress and toxicity in the liver and kidney tissues. It may be concluded that the mixture of $\mathrm{Zn}$ and $\mathrm{Mg}$ supplementation was more beneficial against subchronic toxicity of cadmium. (Bulat et al 2008).
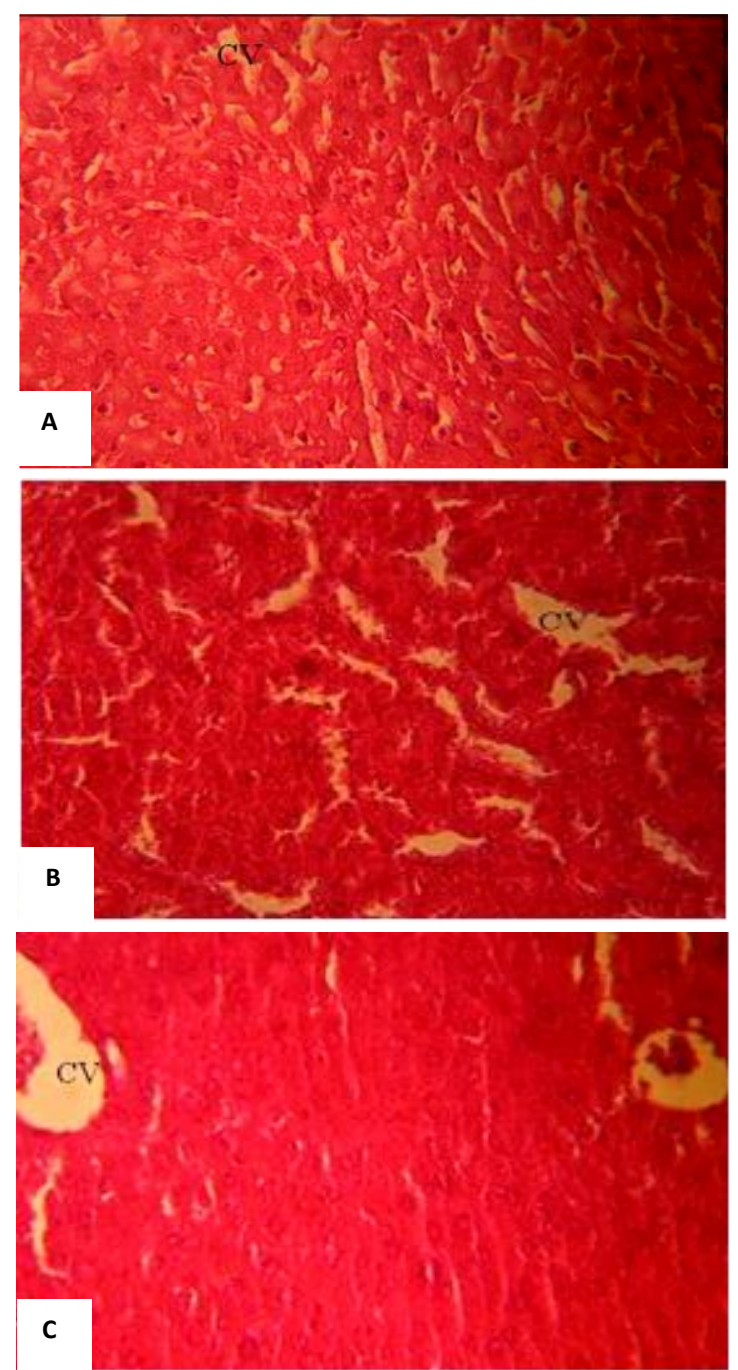

Figure 9 Histological section of the liver of control rats (A), liver of rats treated with Cadmium chloride showing different types of alterations (B) and liver of rats treated with the combination $(\mathrm{Cd}+\mathrm{Zn}, \mathrm{Cd}+\mathrm{Mg})(\mathrm{C})$. (Coloring: hematoxylin-eosin Gr: $\times 400)$; CV: Centrilobular vein. 


\section{Conclusions}

In conclusion, the present study demonstrated that cadmium is a toxic element that causes damages to the liver and neurobehavioral disorders in nervous system (stress and anxiety). Zinc and magnesium have been proven to have protective roles against cadmium toxic effects. The results obtained in the present study showed that zinc or magnesium had nearly the same protective effects against cadmium liver injury. These results suggest that beneficial effects of oral administration of zinc and magnesium. On the other hand, further studies are necessary to explain other possible protective effects of zinc and magnesium in subjects exposed to cadmium and uses other neurobehavioral tests (Forced swimming test) other organs like brain, kidney and testis.

\section{Acknowledgements}

This research work is financially supported by Ministry of Higher Education and scientific research of Algeria. We wish to acknowledge Pr.Abdelkrim Tahraoui head of Applied Neuroendocrinology laboratory Departement of Biology University Badji Mokhtar, Annaba, Algeria, for his help support and encouragement.

\section{Conflict of Interest}

The author declare no conflict of interest.

\section{References}

Ambali SF, Shuaib K, Edeh R, Orieji BC, Shittu M, Akande M (2011) Hyperglycemia induced by subchronic co-administration of chlorpyrifos and lead in Wistar rats: Role of pancreatic lipoperoxidation and alleviating effect of vitamin C. Biology and Medicine 3:6-14.

Andersen O, Nielsen JB, Nordberg GF (2004) Nutritional interactions in intestinal cadmium uptake-possibilities for risk reduction. Biometals 17:543-7.

Bernard A, Roels H, Buchet JP, Cardenas A, Lauwerys R (1992) Cadmium and health: the Belgian experience. IARC Scientific Publications 118:15-33

Bettger JW and Dell BL (1981) Critical physiological role of zinc in the structure and function of biomembranes. Life Sci 28:1425-1438.

Brzoska M, Moniuszko-Jakoniuk J (2000) Interactions between cadmium and zinc in the organism. Food Chem Toxicol 39:967-80.

Brzóska MM, Moniuszko-Jakoniuk J, Piłat-Marcinkiewicz B, Sawicki B (2002)Liver and kidney function and histology in rats exposed to cadmium and ethanol. Alcohol Alcohol 38:2-10.

Bulat ZP, Djukić-Cosić D, Malicević Z, Bulat P, Matović V (2008) Zinc or magnesium supplementation modulates cd intoxication in blood, kidney, spleen, and bone of rabbits. Biol Trace Elem Res 124:110-114

Cempel M and Janicka K (2002) Distribution of nickel, zinc, and copper in rat organs after oral administration of nickel (II) chloride. Biol Trace Elem Res 90:215-226.
Cernaki Savic V, Kotur J, Prokic CV, Kuljic BD, Grbovic Veljovic M (2000) Alterations in magnesium and oxidative status during chronic emotional stress. Magnesium Research 13:29-36.

Comhair SA and Erzurum SC (2002) Antioxidant responses to oxidant-mediated lung diseases. Am Physiol Lung Cell Mol Physiol. 283:246-255.

Contribution à l'étude de conduites émotionnelles chez le rat: Utilisation du handling postnatal et de l'approche éthoexpérimental du comportement (2002) Thèse de doctorat, Université de Rouen, France.

Dawson GR, Crawford SP, Collinson N, Iverson SD and Tricklebank MD (1995) Evidence that the anxiolytic-like effects of chlordiazepoxide on the elevated plus maze are confounded by increases in locomotor activity. Psychopharmacology 118:316-323.

Dhawan D and Goel A (1996) Further evidence for zinc as a hepatoprotective agent in rat liver toxicity. Exp Mol Pathol 63110117.

Dhawan D, Goel A, Gautam CS (1992) Effects of zinc intake on liver enzymes in carbontetrachloride induced liver injury. Med Sci Res 20:55-56.

Djemli S, Fraia A, Frih H, Bachir A, Zaafour M and Djenidi R (2015) Neurobehavioral Effects of Dexamethasone (Inhibition of Adrenal Axis) in Male Mice Mus musculus. Global Veterinaria 15:545-553.

Djemli S, Zine Kechrid Z, Djabar MR (2010) Combined protective effect of zinc and vitamin $\mathrm{C}$ on nickel-induced oxidative liver injury in rats. Scholar Research Library: Annals of Biological Research 3:3278-3286.

Djukić-Cosić D, Ninković M, Malicević Z, Matović V, Soldatović D (2007) Effect of magnesium pretreatment on reduced glutathione levels in tissues of mice exposed to acute and subacute cadmium intoxication: a time course study. Magnes Res 20:177-186.

Dormer RL, Kerbey AL, McPherson M, Manley S, Ashcroft JH, Schofield JG, Randle PJ (1976) The effect of nickel on secretory systems: Studies on the release of amylase, insulin and growth hormone. Biochemistry 140:135-140.

Drury RA, Wallington EA (1980) Carletons histological techniques. Oxford University Press, London, New York Toronto.

El-Refaiy AI, Eissa FI (2012) Protective effects of ascorbic acid and zinc against cadmium-induced histopathological, histochemical, and cytogenetic changes in rats. Comunicata Scientiae 3:162-180.

Erdogan Z, Erdogan S, Celik S, Unlu V (2005) Effects of ascorbic acid on cadmium-induced oxidative stress and performance of broilers. Biol Trace Elem Res 104:19-31.

Finco DR, Kamekeo JJ, Harvey JW, Bruce ML (1997) Kideny fuctions in Clinical Biochemestiry of Domestic Animals. Academic press, San Diego, California. pp. 462-478.

Fraia A, B Ali Rachedi, S Zouiche, S. Djemli and H. Frih (2015) Polyphenon E Could Improve Negative Disorders Changes Caused by Chronic Mild Stress in Male, Wistar Rats. Global Veterinaria 4:478-489.

Golf SW, Bender S, Gruttner J (1998) The significance of magnesium in extreme physical stress. Cardiovascular Drugs and Therapy 12:197-202.

Gurer H, Ozunes H, Neal R, Spitz DR, Ercal N (1998) Antioxidants effects of $\mathrm{N}$-acetylcysteine and succimer in red blood cells from lead exposed rats. Toxicology 120:181-189. 
Hossam El Din Omar, Ahmed Ibrahim, Marwa Magdy, Emad Ahmed (2016) The protective effects of zinc and vitamin E supplementation against kidney toxicity by lithium in rats.European Journal of Biological Research 6:21-27.

Kaplan A (1984) Glucose.Clin.Chem.Toronto. Princeton. pp 10321036.

Kaplan A (1984) Urea.Clin.Chem. Toronto. Princeton. pp 12571260.

Kostic MM, Ognjanovic B, Dimitrijevic S, Zikic RV, Stajnrosic GL,Zivkovic, RV (1993) Cadmium-induced changes of antioxidant and metabolic status in red blood cells of rats: in vivo effects. Eur. J. Haematol 51:86-92.

Kusal KD, Swastika ND, Shakuptala D (2001) The influence of ascorbic acid on nickel induced hepatic lipid peroxidation in rats. Basic Clin Physiol Pharmac 12:187-195.

M Kouadria, S Djemli, A Tahraoui (2019) The protective effect of Zinc and Magnesium against subchronic Cadmium toxicity in Wistar rats (Biochemical and neurobehavioral effects). Asian Journal of Pharmaceutical and Clinical Research 12:217-225.

Mahran AA, Osman HEH, El-Mawla AMAA, Attia AM (2011) Protective effect of zinc ( $\mathrm{Zn}$ ) on the histology and histochemistry of liver and kidney of albino rat treated with cadmium. J Cytol Histol 2:2-9.

Massanyi P, Toman R, Valent M, Cupka P (1995) Evaluation of selected parameters of a metabolic profile and levels of cadmium in reproductive organs of rabbits after an experimental administration. Acta Physiologica andt Hung 83:267-273.

Matović V, Buha A, Bulat Z, Đukić-Ćosić D (2011) Cadmium toxicity revisited: focus on oxidative stress induction and interactions with zinc and magnesium. Arhiv za higijenu rada toksikologiju. 1:6575 .

Matović V, Buha A, Bulat Z, Đukić-Ćosić D (2011) Cadmium toxicity revisited: focus on oxidative stress induction and interactions with zinc and magnesium. Arhiv za higijenu rada toksikologiju. 1:6575 .

Matovic V, Bulat ZP, Dukic-cosic D, Soldatovic D (2004) Zinc, copper, or magnesium supplementation against cadmium toxicity. New York: Nova Science Pub Inc.

Merali Z, Singhal R (1976) Prevention by zinc of cadmiuminduced alterations in pancreatic and hepatic functions. British Journal of pharmacology 57:573-579.

Montgomery K C (1955) The relationship between fear induced by novel stimulation and exploratory behaviour. J. Comp Physio Psychol 48:254-260.

Murry R (1984) Alanine aminotransferase. Clin. Chem. Toronto. Princeton. pp. 1117-1121.

Murry R (1984) Aspartate aminotransferase. Clin. Chem. Toronto. Princeton. pp. 1112-1116.

Murry RL (1984) Creatinine. Clin. Chem. Toronto Princeton. pp 1261-1266.

Nemmiche, D, Chabane, S, Guiraud, P (2007) Role of alphatocopherol in cadmium induced oxidative stress in Wistar rat's blood, liver and brain. Chem. Biol. Interact. 170:221-30.

Nepton Soltani, Mansoor Keshavarz, Hamid Sohanaki, Ahmed Reza Dehpour,Saleh Zahedi Asl (2005) Oral magnesium administration prevents vascular complications in STZ -diabetics rats. Life Sciences $76: 1455-1464$.
Nic Dhonnchadha BA, Bourin M and Hascoët M (2003) Anxiolyticlike effects of 5-HT2 ligands on three mouse models of anxiety. Behav Brain Res 140:203-214.

Noël L, Huynh-Delerme C, Guérin T, Huet H, Frémy J-M, KolfClauw M (2006) Cadmium accumulation and interactions with zinc, copper, and manganese, analysed by ICP-MS in a longterm Caco-2 TC7 cell model. Biometals. 19:473-81.

Obaiah Jamakala A, Usha Rani (2014) Mitigating role of Zinc and Iron against Cadmium induced toxicity liver and kidney of male albino Wistar: a study with reference to Metallothioneine quantification. Int J Pharm Pharm Sci 6:411-417.

Pari L, Murugavel P (2005) Role of diallyl tetrasulfide in ameliorating the cadmium induced biochemical changes in rats. Environ. Toxicol. Pharmacol 20:493-500.

Rana SV, Rekha S, Seema V (1996) Protective effects of few antioxidants on liver function in rats treated with cadmium and mercury. Indian Journal of Experimental Biology 34:177-179.

Rogalska J, Brzóska MM, Roszczenko A, Moniuszko-Jakoniuk J (2009) Enhanced zinc consumption prevents cadmium-induced alterations in lipid metabolism in male rats. Chemico-biological interactions 177:142-52.

Sameeh A, Mansour Abdel-Tawab, Mossa H (2009) Lipid peroxidation and oxidative stress in rat erythrocytes induced by chloropyrifos and the protective effect of zinc. Pesticide Biochemistry and Physiology 93:34-39.

Santon A, Irato P, Medici V, D'Inca R, Albergoni LV, Sturniolo GC (2003) Effect and possible role of Zn treatment in LEC rats, an animal model of Wilson's disease. Biochim Biophys Acta 1637:91-97.

Sidhu P, Singh N, Shahi JS, Garg ML, Dhawan DK (2003) Hepatotoxic effects of differential doses of nickel-a biochemical and elemental profile study. Vinbull 8:589-593.

Sidhu P, Singh N, Shahi J S, Garg ML, Dhawan DK (2006) Zinc protects rat liver histo-architecture from determined effects of nickel. Bio.Metals 19:301-313.

Silvina Alvarez, Nidia Gomez, Luis Scardapane, Fanny Zirulnik, Dante Martinez, Maria Sofia Gménez (2004) Morphological changes and oxidative stress in rat prostate exposed to a non carcinogenic dose of cadmium. Toxicology letters. 153:365-376.

Simons JE, Yang RSH, Berman E (1995) Evaluation of the mixtures containing organic metals advantages and deasvantages of the use of red world complex mixtures. Environ Health Perspect 103:67-71.

Slotkin TA, Mac Killop EA, Ryde IT,Tate CA, Seidler FJ (2007) Screening for developmental neurotoxicity using PC12 cells: comparisons of organophosphates with a carbamate, anorganochlorine, and divalent nickel. Environ Health Perspect 115:93-101.

Smialowicz RJ, Rogers RR, Riddle MM, Leubke Fogelson LD, Rowe DG (1987) Effects of manganese, calcium, magnesium, and zinc on nickel induced suppression of murine natural killer cell activity. Toxicol Environ Health 20:67-80.

Soldatovic D, Vujanovic D, Matovic V,Plamenac Z (1997) Compared effects of high oral $\mathrm{Mg}$ supplements and of EDTA chelating agent on chronic lead intoxication in rabbits. Magnesium research: official organ of the International Society for the Development of Research on Magnesium 10:127-33.

Solomons NW, Viteri F, Shuler TR, Nielsen FH (1982) Bioavailability of nickel in man effects of foods and chemically 
defined dietary constituents on the absorption of inorganic nikel. Nutr 112:39-50.

Soubrié D (1971) Open-Field chez le rat: inter-relations entre locomotion exploration et emotivité. Journal of Pharmacology 2:457472.

Sugiwara N (1977) Inhibitory effect of cadmium on calcium absorption from the rat duodenum. Arch. Environ. Contam Toxicol 5:167-175.

Sunderman Jr, Kasprzak KS, Horak E, Gitltz P, Onkelinx C (1976) Effect of triethylenetetramine upon the metabolism and toxicity of $63 \mathrm{NiCl} 2$ in rats. Toxicology Applied Pharmacology 38:177-188.

Tandon A, Nagpaul JP, Bandhu H, Singh N, Dhawan D (1999) Effect of lithium on hepatic and serum elemental status under different dietary protein regimens. Biol Trace Elem Res 68:51-62.

Tandon SK, Singh S, Prasad S, Mathur N (2001) Hepatic and renal metallothionein induction by an oral equimolar dose of zinc, cadmium or mercury in mice. Food Chem Toxicol 39:571-577.
Treit D M, Menard J, Royan C (1993) Anxiogenic stimuli in the elevated plus-maze. Pharmacol Biochem Béhaï 44:463-469.

Uyanik F, Eren M, Atasever A, Tuncoku G, Kolsuz AH (2001) Changes in some biochemical parameters and organs of broilers exposed to cadmium and effect of Zinc on cadmium induced alteration. Israel Veterinary Medicine 56:128-134.

Waalkes MP, Kasprzak KS, Oshima M, Poirier LA (1985) Protective effects of zinc acetate towards the toxicity of nickelous acetate in rats. Toxicology 39:29-41.

Washko PW, Cousins RJ (1977) Metabolism of Cd109 in rats fed normal and low-calcium diets. Toxicol Environ Health 1056-1066.

WHO (World Health Organisation) (1992) Environmental Health Criteria, 134Cadmium. IPCS: Geneva. 